\title{
Allergy to tree-of-heaven pollen in Germany: detection by positive nasal provocation
}

\author{
Karl-Christian Bergmann · Matthias Werchan · Barbora Werchan
}

Received: 4 November 2019 / Accepted: 9 January 2020 / Published online: 20 February 2020

(C) The Author(s) 2020

Keywords New allergen · Allergic rhinitis · Rare allergens · Invasive tree species · Climate change

\section{To the editors}

The European Union recently (25 July 2019) added the tree-of-heaven (Ailanthus altissima (Mill.) Swingle) in the Simaroubaceae family to the "list of invasive alien species of EU concern". Therefore, this tree is now under observation and the import, trade, and planting of tree-of-heaven in public areas are prohibited [1]. As a result, an earlier (2012) recommendation of ours on the planting of this tree in public areas must be withdrawn [2].

This deciduous broad-leaved tree (Fig. 1) is indigenous to parts of China and Vietnam and can already be found on all continents, with the exception of the Antarctic [3]. In Germany, it favors warm, sunny locations and is therefore found in particular within urban heat islands. The tree is expected to increasingly spread beyond these heat islands as a result of global warming [4]. The tree-of-heaven's growth rate is remarkable and it already produces seeds from the age of 3 years. It flowers in June and July (Fig. 2) and is primarily insect-pollinated. However, its pollen (Fig. 3) can also be spread by wind [5].

The allergenic effect of the pollen is known in Asia and the Middle East [6]. Thus, for example, approx-

Prof. Dr. K.-C. Bergmann $(\bowtie) \cdot$ M. Werchan · B. Werchan German Pollen Information Service Foundation (Stiftung Deutscher Polleninformationsdienst), Charitéplatz 1, 10117 Berlin, Germany

karlchristianbergmann@gmail.com

Prof. Dr. K.-C. Bergmann

Klinik für Dermatologie, Venerologie und Allergie, Charité Universitätsmedizin Berlin, Luisenstr. 2, 10117 Berlin Germany

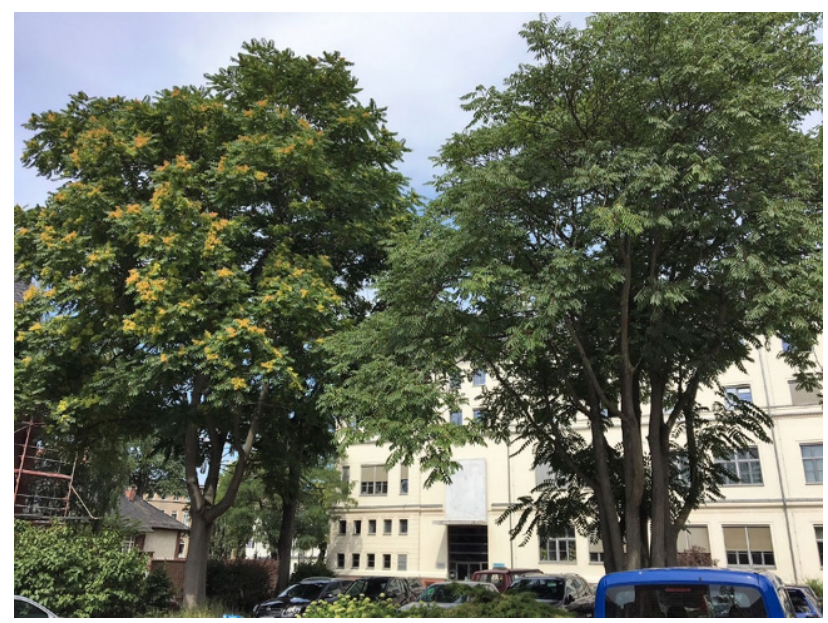

Fig. 1 Female (left) and male (right) tree-of-heaven on the grounds of the Charité, Campus Mitte, Berlin, Germany (@ Karl-Christian Bergmann)

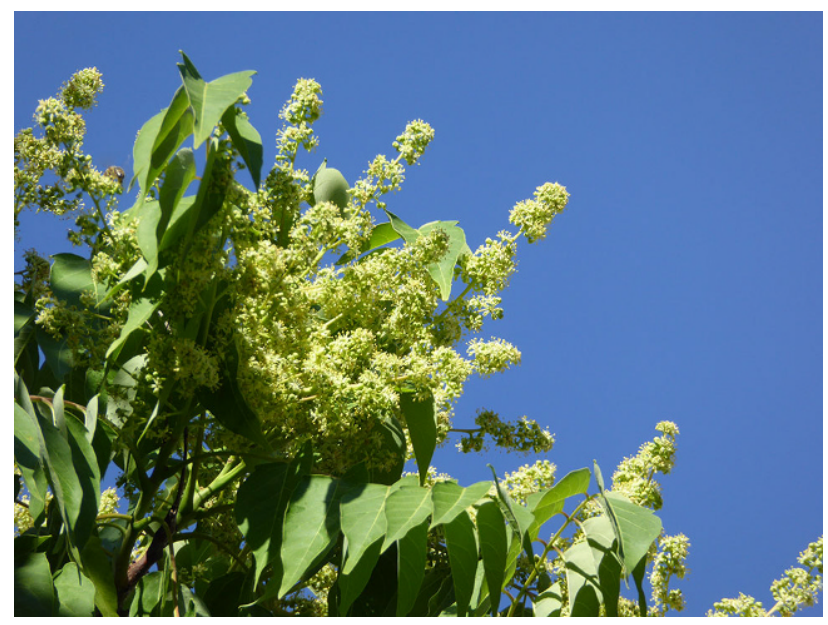

Fig. 2 Tree-of-heaven blossom with male flowers (@ Matthias Werchan) 
Fig. 3 Tree-of-heaven (Ailanthus altissima) pollen grain in two different focal planes at $400 \times$ magnification under a light microscope, stained with safranin (C Barbora Werchan)

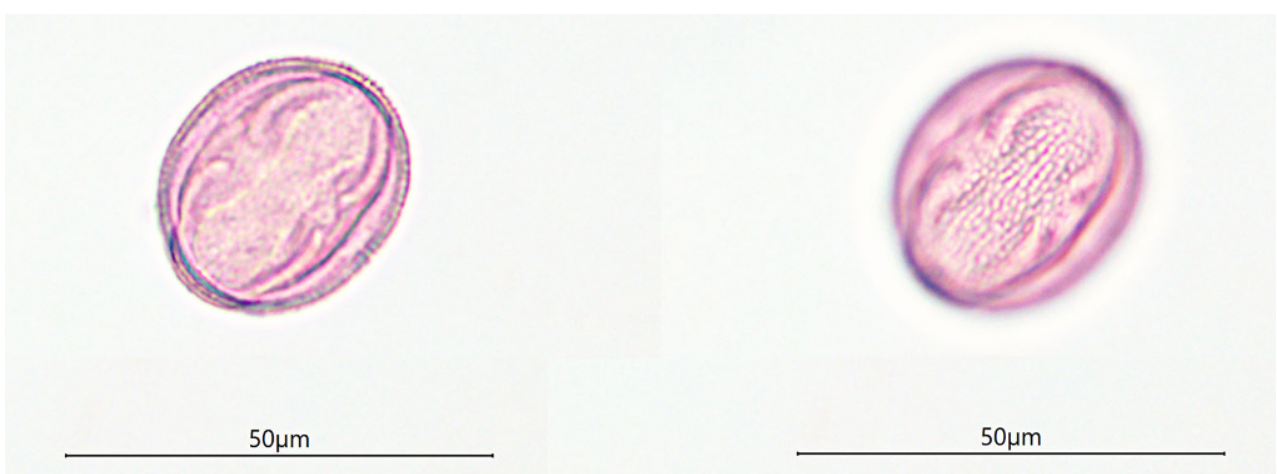

Fig. 4 Reduction in nasal flow upon nasal provocation with Ailanthus pollen. Positive nasal inspiratory flow (PNIF) is shown before, 10 min after $\mathrm{NaCl}$, and 15 min after Ailanthus pollen in both sides of the nose

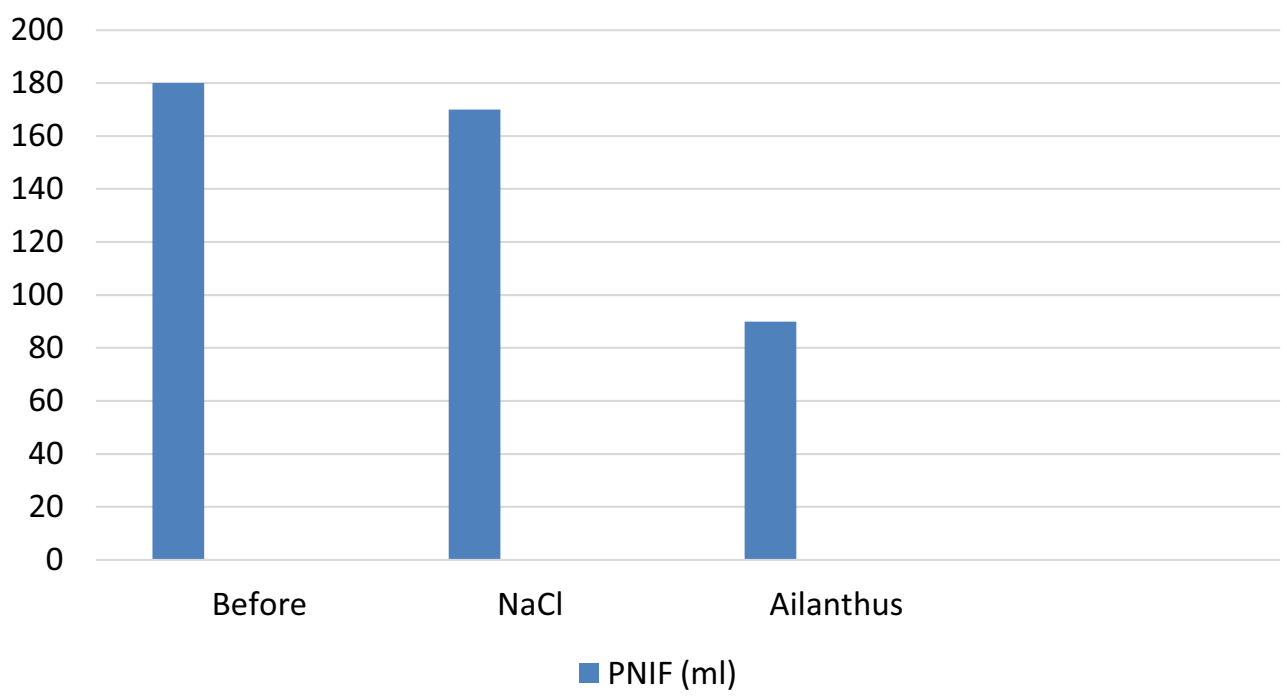

imately $30 \%$ of 44,994 patients of all age groups in Beijing, China, tested positive to skin prick testing for suspected allergic rhinitis ( $\geq 5 \mathrm{~mm})$ [7].

After we also found specific IgE antibodies to Ailanthus in the blood of adults with allergic rhinitis in Berlin, Germany, the question arose as to whether we were dealing with clinically silent sensitization or whether nasal provocation testing could also elicit positive reactions.

The first of our patients to test positive (male, $172 \mathrm{~cm}, 90 \mathrm{~kg}$, born in 1961 in Sri Lanka and living in Germany, Berlin-Tiergarten, since 1985) presented with rhinoconjunctivitis in the summer months and allergic asthma. In view of a high total $\operatorname{IgE}$ of $2685 \mathrm{kU} / \mathrm{L}$ and the detection of multiple specific IgE antibodies (laboratory: Berlin-Charité Vivantes $\mathrm{GmbH}$ ) to tree-of-heaven (Rt300, Thermo Fisher Scientific $\mathrm{GmbH}$, Dreieich, Deutschland)) at $6.8 \mathrm{kU} / \mathrm{l}$ and other trees (oak t7 = $4.1 \mathrm{kU} / \mathrm{l}$; elm t8 $=19.2 \mathrm{kU} / \mathrm{l}$; plane $\mathrm{t} 11=3.4 \mathrm{kU} / \mathrm{l}$; linden $\mathrm{t} 208=3.4 \mathrm{kU} / \mathrm{l})$, the patient gave informed consent to nasal provocation testing with Ailanthus altissima pollen (origin, Bonapol, a.s., České Budějovice, Czech Republic). At $15 \mathrm{~min}$ following bilateral nasal provocation with the pollen, the patient developed itching, sneezing, and nasal congestion, as well as a $51 \%$ reduction in peak nasal inspiratory flow
(PNIF) as a manifestation of a local allergic reaction (Fig.4), which ceased after a further $30 \mathrm{~min}$ without medication.

The authors believe that this is the first patient in Germany to test positive to nasal provocation for allergic rhinitis due to tree-of-heaven pollen. The patient's Sri Lankan origin is undoubtedly relevant to his sensitization, which would have occurred during the first 24 years of his life spent in Sri Lanka. It is also not possible to definitively conclude from the patient history whether his symptoms in Berlin are indeed caused by Ailanthus pollen. Positive nasal provocation can be considered as evidence that individuals that have become sensitized to Ailanthus pollen in their countries of origin also react to tree-of-heaven in Germany.

We will investigate in a targeted manner symptoms in any other adults (born in Germany) with proven sensitization.

Anyone interested in new sensitizations and potential new allergies as a result of climate change should keep an eye on the spread of this tree in their area.

Acknowledgements The authors would like to thank Phadia $\mathrm{GmbH}$ for making the test reagents for IgE antibody determination available at no cost.

Funding Open Access funding provided by Projekt DEAL. 
Conflict of interest K.-C. Bergmann states that he did not receive financial support from Thermofisher Scientific GmbH. M. Werchan states that he did not receive financial support from Thermofischer Scientific GmbH. B. Werchan states that she has no conflicts of interest.

Open Access This article is licensed under a Creative Commons Attribution 4.0 International License, which permits use, sharing, adaptation, distribution and reproduction in any medium or format, as long as you give appropriate credit to the original author(s) and the source, provide a link to the Creative Commons licence, and indicate if changes were made. The images or other third party material in this article are included in the article's Creative Commons licence, unless indicated otherwise in a credit line to the material. If material is not included in the article's Creative Commons licence and your intended use is not permitted by statutory regulation or exceeds the permitted use, you will need to obtain permission directly from the copyright holder. To view a copy of this licence, visit http://creativecommons.org/licenses/by/4.0/.

\section{References}

1. Regulation (EU). No 1143/2014 of the European Parliament and of the Council of 22 October 2014 on the prevention and management of theintroduction and spread of invasive alien species. 2014on. 2019. http://data.europa.eu/eli/ reg/2014/1143/oj. Accessed28 Oct2019.

2. Bergmann KC, ZuberbierT, Augustin J, MückeH-G, StraffW. Klimawandel und Pollenallergie: Städte und Kommunen sollten bei der Bepflanzung des öffentlichen Raums Rücksicht auf Pollenallergiker nehmen. Allergo J. 2012;21:103-8.

3. Kowarik I, Säumel I. Biological flora of central europe: ailanthus altissima (mill.) Swingle. Perspect Plant Ecol Evol Syst. 2007;8:207-37.

4. Nehring S, Kowarik I, Rabitsch W, Essl F. Naturschutzfachliche Invasivitätsbewertungen für in Deutschland wild lebende gebietsfremde Gefäßpflanzen. BfN-Skripten, Vol. 352. 2013. pp. 1-202.

5. Werchan M, Werchan B, Bergmann KC. Der Pollen des Götterbaums (Ailanthus altissima) - ein seltenes Allergen in Deutschland. Allergo J Int. 2019;28(6):209-54. P2.9:75.

6. Majd A, Rezanejad F, Irian S, Mousavi F. Hypersensitivity to Ailanthus altissima (tree-of-heaven) pollen: identification of a major IgE-binding component. Aerobiologia. 2013;29:407-12.

7. Werchan M, Zhi Y, Gu J, Werchan B, Bergmann KC. High frequency of sensitization to the native Tree-ofHeaven (Ailanthus altissima [Mill.] Swingle) in Beijing, China. ICA 2018-11th Intern. Congress on Aerobiology; 03.-07.09.2018; Parma. 